\section{Investigation of the geomechanical state
of soft adjoining rocks under protective \\ Investigation of the geomechanical state
of soft adjoining rocks under protective constructions}

Rudarsko-geološko-naftni zbornik (The Mining-Geology-Petroleum Engineering Bulletin) UDC: 622.26: 622.83

DOI: $10.17794 / \operatorname{rgn} .2021 .4 .6$

Original scientific paper

\author{
Serhii Nehrii', Tetiana Nehrii ${ }^{1}$, Oksana Zolotarova $^{1}$, Serhii Volkov ${ }^{1}$ \\ ${ }^{1}$ Donetsk National Technical University, 2, Shybankova Square, Pokrovsk, Donetsk region, 85300, Ukraine.
}

\begin{abstract}
The conditions of coal seam mining in the mines of Ukraine have been considered. The problem of conducting coal mining by longwalls in the conditions of soft adjoining rocks, which concerns the protection of mine roadways located near the face, has been revealed. In such conditions, the existing protective constructions are ineffective due to the fact that they yield and get pressed into the soft rocks of the footwall. This indicated the need for research into the geomechanical state of soft rocks of the footwall. According to the results of known studies on the mechanism of rock mass failure around roadways and the data of physical and mechanical properties of the coal mass, which is represented by soft rocks, the correlation dependence has been obtained, the use of which allowed for the determination of the parameters of the rock deformation diagram and the establishment of the stability criterion of footwall rocks under the protection means and stability conditions of the geotechnical system "protective construction - adjoining rocks." They are the basis of a new approach to ensure the stability of the roadways, which are supported behind the faces, by controlling the stress state in the system "protective construction - adjoining rocks." This may be the basis for the development of new methods of protecting roadways in conditions of soft adjoining rocks.
\end{abstract}

Keywords:

longwall mining systems; soft rocks; protective construction; rock failure; stability criterion

\section{Introduction}

Coal is still an important energy source for many countries of the world. Ukraine is no exception, where proven coal reserves are almost 34 billion tons, which is almost $4 \%$ of the world (URL1).

Coal mining in Ukraine is carried out underground. Thin and medium-thickness layers with a drop from horizontal to steep are mainly developed. Working out of layers is produced by long columns through stretching, falling or rising. This technology is widespread throughout the world, when the extraction is carried out by longwalls, which are serviced by roadways, and are mostly protected in the rock mass and by coal pillars (see Figure 1) (Galvin, 2016). Longwall mining systems are generally characterized by high productivity, low operation costs, and continuity of operations (Heydari et al., 2020; Norouzi et al., 2021). However, this technology has some disadvantages: a high level of injuries (Nehrii et al., 2018; Aghababaei et al., 2020) and limited use

Corresponding author: Serhii Nehrii

serhii.nehrii@donntu.edu.ua on the soft adjoining rocks due to significant deformations in the adjacent faces and roadways (Nehrii, Sakhno et al., 2018; Bondarenko et al., 2021).

For most mines in Ukraine, leaving coal pillars to protect the roadways is unacceptable due to significant mineral loss, or because coal may be prone to spontaneous combustion (Gamiy et al., 2020). Therefore, as a rule, they use technologies where artificial constructions made of wood, concrete, ordinary rock, etc. (see Figure 2) are used instead of pillars. However, in any case, there is a general problem of ensuring the operational condition of the mine roadways adjacent to the breakage faces and are in the zone of their influence. This question is most relevant in conditions when there are soft adjoining rocks around, the strength of which is less than $40 \mathrm{MPa}$ for uniaxial compression.

Pillars or artificial protective constructions that are supposed to ensure the maintenance of roof rocks and the operational condition of the adjacent working space (in the face, chamber, roadway) in the conditions of soft adjoining rocks are ineffective due to the fact that, in addition to their contraction, they are also pressed into the footwall rocks. All these processes inevitably lead to 


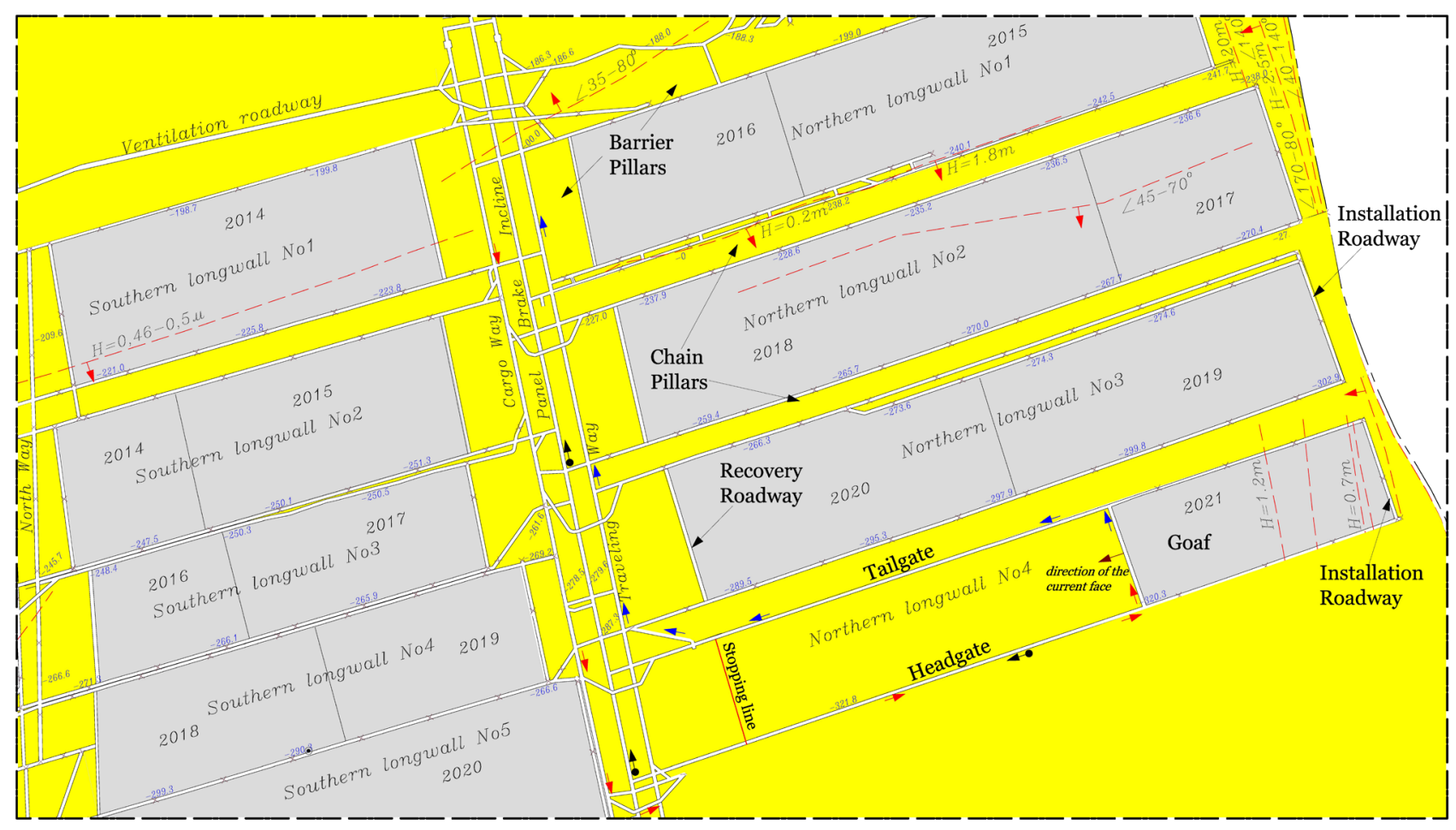

Figure 1: Scheme of underground coal seam development by longwalls

landslides and loss of cross-section of the working space. This is well illustrated in the paper (Galvin, 2016), which shows the mechanism of pressing protection constructions and its consequences. The work (Dolinar, 2010) shows how cylindrical supports are pressed into the footwall, after which rock protrusion shafts are formed around them. The same pattern is observed around pillars (Zhao, 2017), wooden cribs (Chase, 2002) and other protective constructions.

In the conditions of soft adjoining rocks of coal mines in Ukraine, contraction and pressing of protective constructions, which are set next to the roadway behind the face, are also observed. This mechanism is illustrated in Figure 3. The pressing of the protective construction adjacent to the roadway is identical to the pressing of the construction shown in Figure 4. This has been proven by the results of numerical simulations in the study of the mechanism of pressing the constructions which are located near the roadway (Nehrii, Kultaev et al., 2020) and further away (Nehrii, Bachurin et al., 2019).

The main factors that determine the displacement of rocks on the contour of the roadways are (Farmer, 1985): stresses around the workings and arising as a result of mining, coal seam rigidity, the strength of adjoining rocks and their water content, geological features around the workings, the method of working out, parameters of roadway walling, the mutual spacing of breakage faces and the yield of the applied protective construction.

Consequences of deformations of rocks and fastenings of roadways supported behind a breakage face are hanging and éboulement of rocks outside the next-to-longwall space (Dychkovskyi et al., 2020). The nature of these deformations largely depends on the type of protective construction. Rigid protective construction prevents the lowering and stratification of roof rocks, but pliable protective construction leads to a significant lowering of rock layers, their failure and éboulement. At the same time, the rigid means of protection cause a significant heaving of the foot rocks, whereas the pliable ones slow down this process. In general, increasing the rigidity of constructions leads to improvement in the condition of the roadways, except for conditions with soft rocks. In this case, the increase in the rigidity of the constructions is reduced by their pressing into the foot. So, on soft footwall rocks, it is necessary to ensure a balance in the geotechnical system «means of protection - adjoining rocks.» To do this, in addition to reducing the pliability of the protective construction, it is necessary to ensure the stability of the rocks on which it is located. This issue is relevant for coal mines in Ukraine, which are worked within the promising areas of Donbas, where the adjoining rocks are represented by soft shales. However, it is no less relevant for coal and ore mines with similar mining and geological conditions. In order to develop any engineering solutions to ensure the system, it is necessary to study the geomechanical state of the adjoining rocks around the protective constructions, which this article is devoted to. Therefore, its purpose is to study the geomechanical state of soft adjoining rocks under protective constructions. 


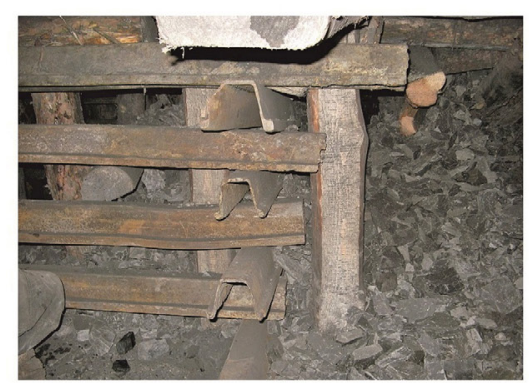

Four-point metal cribs

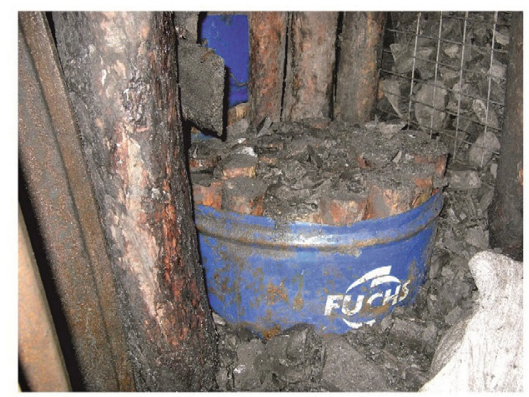

Supports made of wooden posts in a metal frame

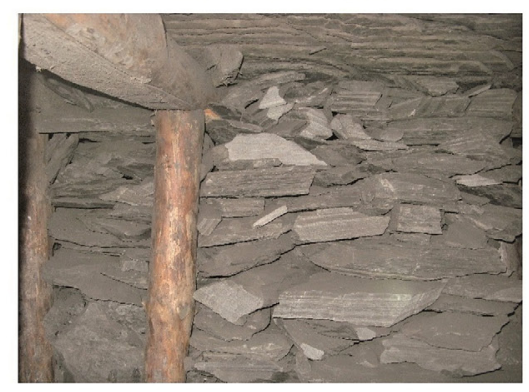

Strip of ordinary rock

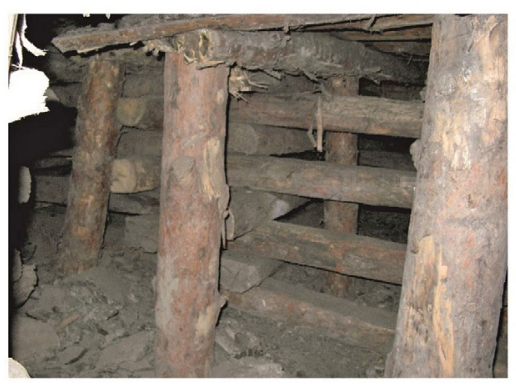

Four-point wooden cribs

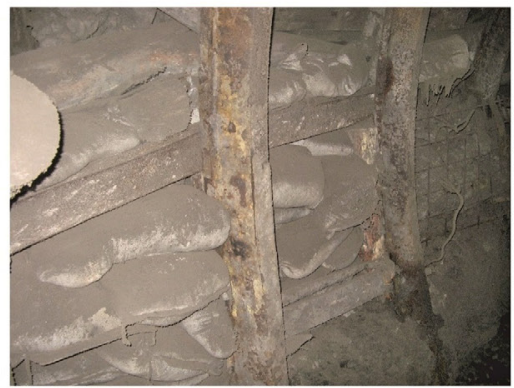

Concrete bag supports

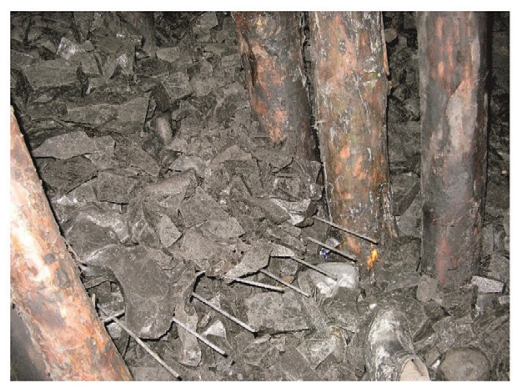

Strip of ordinary rock which is reinforced with a metal mesh

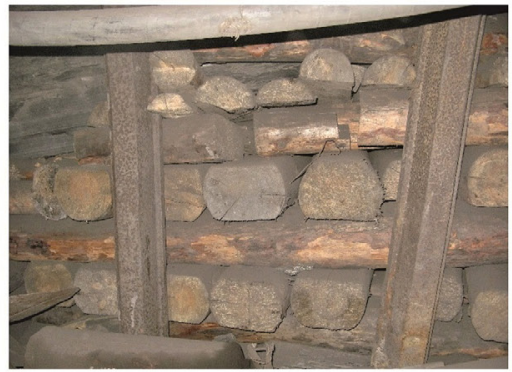

Multi-point wooden cribs

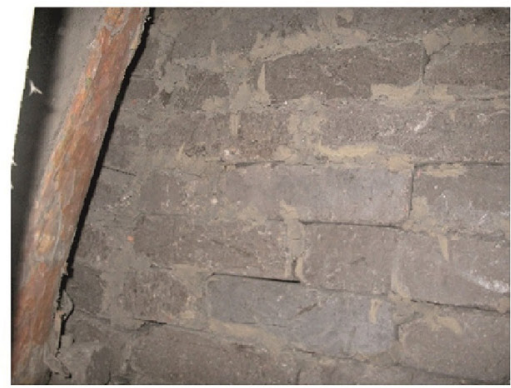

Wall of rock-cement blocks on clay

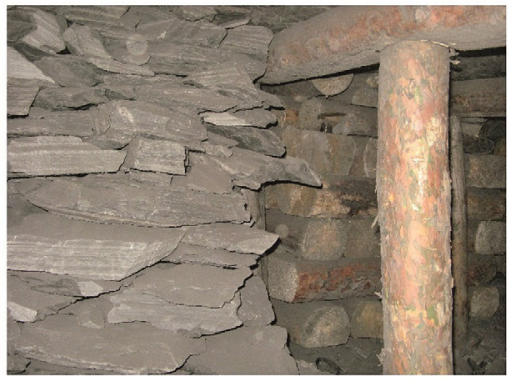

Strip of rock with wooden cribs

Figure 2: Photos of artificial constructions for the protection of mine roadways

\section{Methods}

Consider this question on the example of coal mines, where the coal-bearing stratum is represented by soft adjoining rocks, the strength of which does not exceed $40 \mathrm{MPa}$.

Methods that have been used to achieve the goal: analysis and generalization of modern scientific and technical achievements in the field of protection of development workings, methods of geomechanics, correlation analysis, analysis and interpretation of the obtained results.

The stability of the rocks underlying the means of protection depends on their physical and mechanical characteristics, water content and the degree of failure. A manifestation of the loss of stability of the underlying rocks is the subsidence of protection means relative to their surface. This subsidence provokes the displacement of the roof rocks both over the protective construction and over the roadway. It is also accompanied by extrusion of the footwall rocks into the cavities around the means of protection, including in the roadway which is protected. In such conditions, it is important to study the mechanism of indentation of protection means in the footwall rocks and to establish the main factors on which the magnitude of their subsidence depends. Their results can be the basis for the development of measures to ensure balance in the geotechnical system "protective construction - adjoining rocks."

The processes of deformation and failure of the rock mass containing the roadway, are studied in (Petrenko, 2008; Zong et al., 2020). An analytical-experimental method for calculating the size of the zone of inelastic deformations, consisting of the zone of destroyed rocks and the zone of plastic deformations, has been suggested. In particular, Equation 1 has been proposed to predict the size of the area of destroyed rocks, which is:

$$
\frac{r_{z}}{r_{w}}=0.763 \dot{a}^{1.104 \frac{\gamma \dot{I}}{\sigma_{\hat{i}} k_{\tilde{n}}}}
$$





Figure 3: Scheme and photos of displacement and failure of the rock mass around the mine roadway: $U_{r r}, U_{r f}-$ accordingly, displacement of roof rocks and footwall of a roadway; $U_{s}$ - the value of subsidence of protection means; $U$ - displacement of roof rocks over the protection means

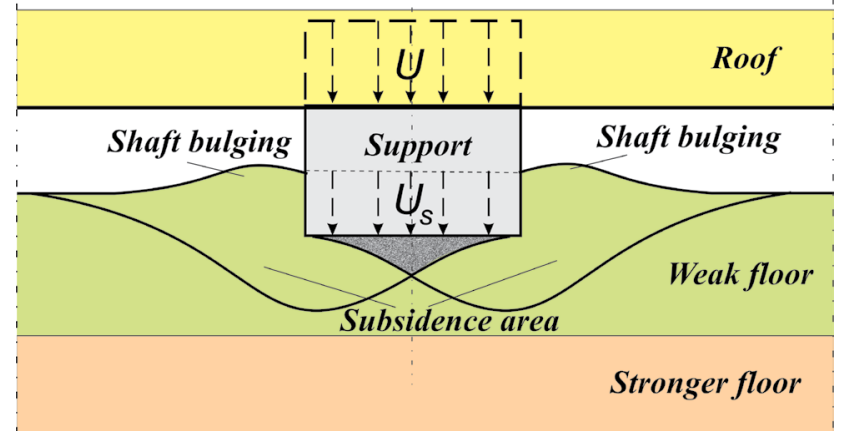

Figure 4: Scheme of pliability and indentation of a support in a weak floor

\section{Where:}

$r_{z}-$ is the radius of the zone of destroyed rocks $(\mathrm{m})$,

$r_{w}$ - initial radius of roadway $(\mathrm{m})$, $\gamma \quad$ - volume weight of rocks $\left(\mathrm{MN} / \mathrm{m}^{3}\right)$,

$H$ - depth of placement of roadway (m),

$\sigma_{o}$ - conditional instantaneous strength of rocks (MPa),

$k_{c}$ - the coefficient of structural weakening of rocks (un.), $\left(k_{c}=0.2 \ldots 0.9\right)$ (Bondarenko et al., 2008).

From Equation 1 it follows that the place of construction of protective equipment falls on the area of destroyed rocks (see Figure 5), which is already fully or partially formed by the time of maintenance of the roadway in the area of influence of the mining works. Then the resistance of the accontour rocks is determined by the residual strength of the rocks $R_{r e s}(\mathrm{MPa})$, which characterizes the ability of rocks to maintain load-bearing capacity as a whole construction. The geomechanical balance of the discrete rock environment around the protection means is ensured by the residual strength of the 


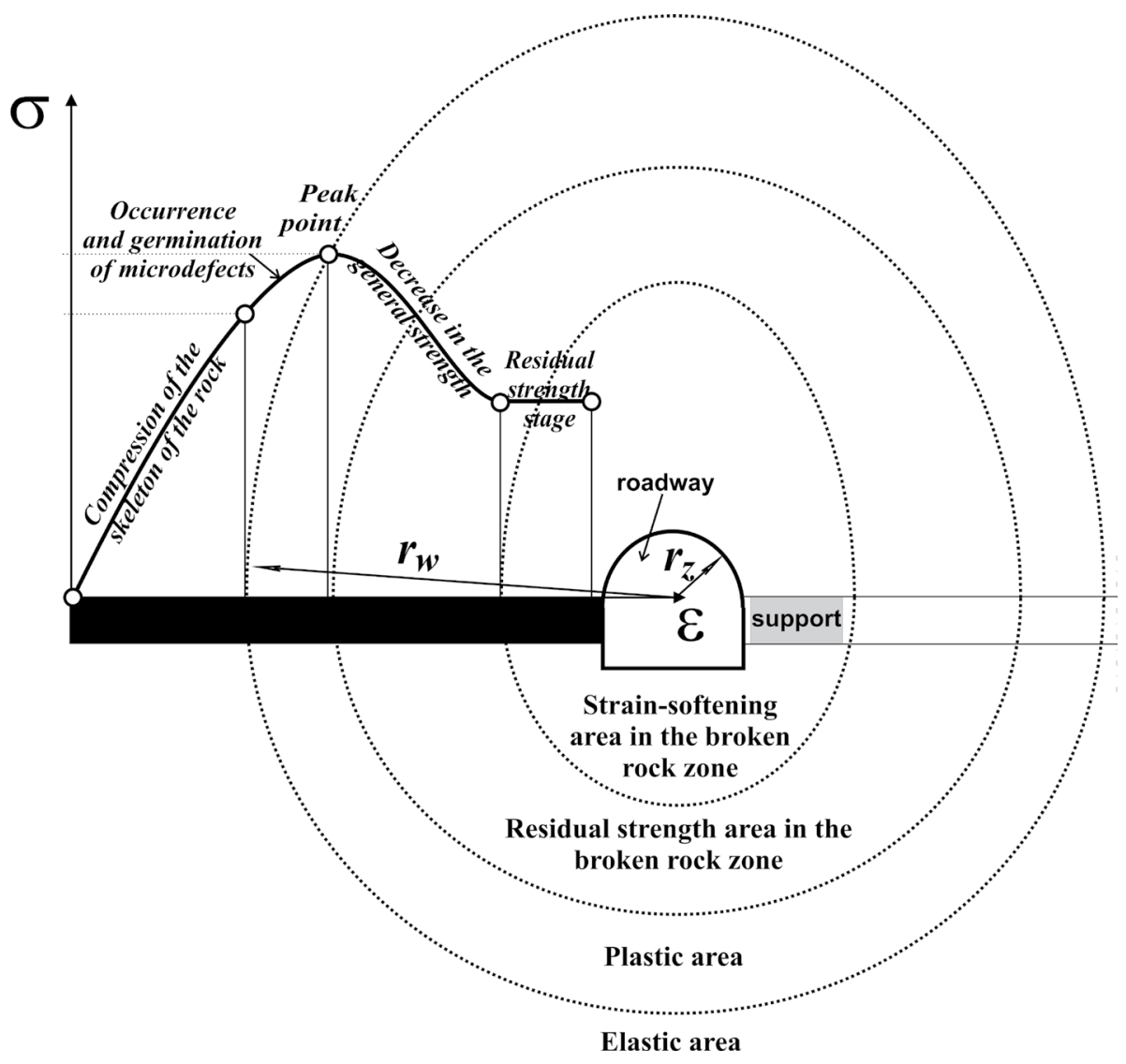

Figure 5: Corresponding relation between surrounding rock in broken zone around the roadway and a complete stress-strain curve

destroyed rocks, which is maintained on a significant range of further deformations.

Deformation of the accontour rock mass is characterized by two stages (see Figure 6): pre-limiting and overlimiting. The boundary between these stages is the ultimate resistance of rocks to compression, exceeding which their destruction and drop in strength to residual, which depends on the type of rocks and the value of adjoining resistance and, according to many studies, is from 3 to $95 \%$ of ultimate strength (Abdullah and Amin, 2008; Brady and Brown, 2006; Jie et al., 2017; Tutluoglu et al., 2015; Yang et al., 2018; Babyiuk, 2005; Bondarenko et al., 2008; Solodiankyn, 2009). These data are mostly based on the results of tests of rock samples and can be extended to the rock mass.

According to the "correspondence hypothesis" (Hapieiev, 2014), the mechanical phenomena that occur during the "hard" failure of the rock specimen in the mode of given deformations (see Figure 6) correspond to the processes occurring when deforming an arbitrary unit volume of rock mass around the mine. In this case, the role of the "rigid" loading device is played by the area of the rock environment, which is elastically deformed and located behind the area of inelastic deformations. The upper branch of the complete deformation diagram (see Figure 6) is responsible for the formation of the external dimensions of the zone of inelastic deformations, and the lower - for movement on the contour of the roadways, which allows for an accurate prediction and ensures the stability of roadways (Hapieiev, 2014). However, the strength of the rocks in the sample differs significantly from the strength of the rocks in the mass, but the difference between the strength in the rock mass and the strength of the sample is estimated by the coefficient of structural weakening.

In the pre-limiting stage between stresses and deformations, there is a connection close to linear to the ultimate strength, and the modulus of elasticity $E$ (conditionally - instantaneous modulus of deformation) in this zone remains constant. At the over-limiting stage, the strength of the samples decreases nonlinearly (Maslo, 2014), but at any load level, the remaining structural bonds provide their strength and ability to elastic deformation, as evidenced by hysteresis loops obtained under cyclic loading and unloading (Shashenko et al., 2008). In many works (Babyiuk, 2005; Solodiankyn, 2009; Shashenko et al., 2008) the simplistically accepted parallelism of hysteresis loops and the modulus of deformation of rocks in the over-limiting area $E_{n}$ is equal to the modulus of elasticity $E$. Such equality was introduced to solve certain problems, but to establish the reasons for indentation of protective constructions in the underlying rocks, this simplification is not appropriate, because the modulus of deformation characterizes the stiffness of the 


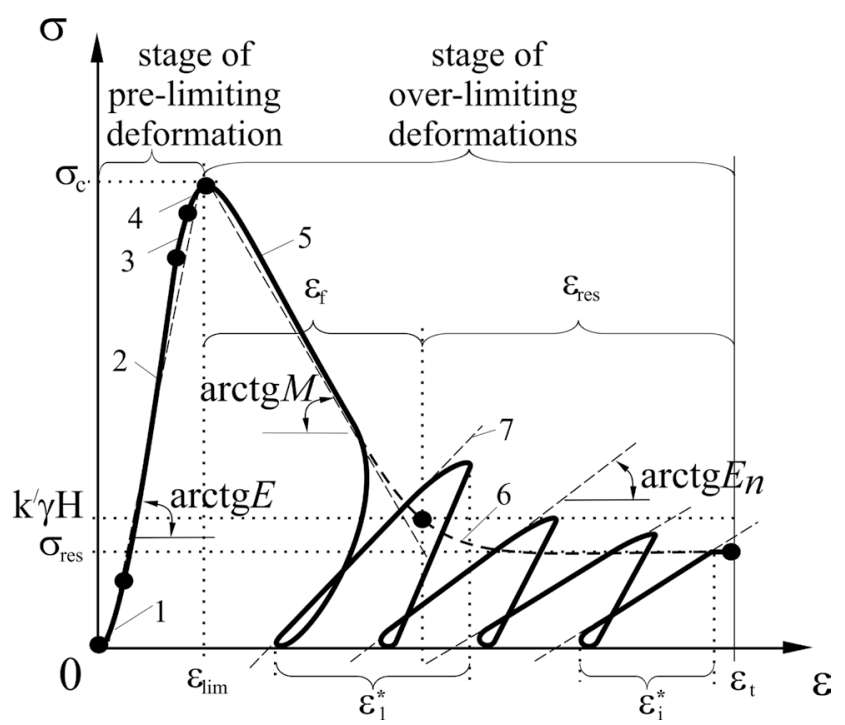

Figure 6: A diagram of deformation of rock in the mode of the set deformations: 1 - compaction due to changes in porosity, 2 - compression of the skeleton of the rock, 3occurrence of microdefects, 4 - germination of microdefects and intergrowth of isolated cracks, 5 - spread of open cracks and decrease in the general strength, 6 - residual friction of destroyed rocks, $7-\mathrm{a}$ line coinciding with the declination of the hysteresis loop, $\sigma_{c}$ - stresses at the limit of strength, $\sigma_{\text {res }}$ - residual strength of the rock when testing samples, $\mathrm{e}_{\text {lim }}$ - longitudinal deformations at the limit of strength, $\mathrm{e}_{\text {res }}$ - longitudinal deformation at the boundary residual strength, $\mathrm{e}_{t}$ - the total longitudinal deformations, $\mathrm{e}_{f}$ longitudinal deformations in the area of reducing the overall strength, $E$ - conditionally-instantaneous modulus of rock deformation, $E_{n}$ - deformation modulus at the residual strength limit, $M$ - recession module, $k^{\prime} \gamma H$ - stress as a result of the load by means of protection, $\mathrm{e}_{1} . . . \mathrm{e}_{i}$ - longitudinal deformations of the destroyed rocks on the corresponding deformation cycle

rocks and its over-estimation leads to a misrepresentation of the result. Indeed, this modulus is several times smaller than the modulus of elasticity. For example, according to (Lezyna, 1992) it was found that for coal samples with a strength of $23 \mathrm{MPa}$ (without adjoining pressure), the modulus $E_{n}(400 \mathrm{MPa})$ is 6 times smaller than the modulus $E(2400 \mathrm{MPa})$. In (Ruppeneit, 1975), the values of these modules were determined in the calculations, taking into account the fractured rocks, according to which the $E / E_{n}$ ratio for some rocks is from 3.05 to 11.0. For rock specimens, this ratio is 5.9 (Matveev, 2012), and for the rock mass - 3.2 (Baklashov and Kartozyia, 1975). So, on average for samples of soft rocks, in the calculations we can take $E / E_{n}=6.0$, but the most accurate will be its experimental evaluation.

To simplify the calculations, take a linear approximation of some sections of the deformation graph, which is used in many studies (Alejano et al., 2009; Lin et al., 2018; Santarelli, 1987; Babyiuk, 2005; Solodiankyn, 2009; Shashenko et al., 2008). In this case, the hysteresis loops are absent, and unloading and reloading occur in a straight line. This determines the achieved residual deformation. This approach was used in the study (Solodiankyn, 2009). The modulus of deformation of rocks in the area of residual strength $E_{n}$ was equal to the modulus in the elastic section $E$, although they differ. The linearity of the sections of the diagram is justified when the values of loads do not exceed the ultimate and residual strength in the respective sections of rock deformation and in the area of the descending part of the diagram. When the residual strength is exceeded, the structural bonds in the destroyed rock volume are broken, with its subsequent compaction. This compaction may be accompanied by displacements and rotation of the rock pieces with each other. The sections of the diagram where these deformations take place are nonlinear, and their linearization requires scientific substantiation. Further, we proceed to determine the parameters of the deformation diagram of the rock mass.

To study the behavior of destroyed underlying rocks, it is advisable to operate not only strength but also deformation properties, as the latter characterize the elastic and plastic deformation of rocks under loads. There is a correlation between rock strength and modulus of elasticity based on porosity (Rzhevskyi and Novyk, 1984), which can be shown as degree (Santarelli, 1987; Tutluoglu et al., 2015) or linear (Deere and Miller, 1966; Singh and Ghose, 2006; Hobbs, 1971; Kartashov et al., 1979; Rzhevskyi and Novyk, 1984) dependencies. In the latter case, according to tests of samples of different rocks, it can be represented by Equation 2:

$$
\sigma_{\tilde{n} s}=(0.00127 \ldots 0.005) E
$$

Where:

$\sigma_{c s}-$ uniaxial compressive strength (MPa),

$E$-(Elastic Modulus) conditional instantaneous modulus of deformation of the rock (MPa),

$(0.00127 \ldots 0.005)$ - the range of changes in the longitudinal deformation of different rocks depending on the type and nature of their load. This range includes most mining rocks (Abdullah and Amin, 2008; Santarelli, 1987; Singh and Ghose, 2006; Tutluoglu et al., 2015).

The area of the descending part of the deformation diagram (see Figure 6), where open cracks expand and the overall strength decreases, can also be described by a linear dependence (Babyiuk, 2005; Fadeev, 1987; Shashenko et al., 2008), and its angle is characterized by a decay modulus $M$, or fragility. The modulus of decline can be expressed by Equation 3:

$$
M=\frac{\sigma_{\tilde{n}}-\sigma_{r e s}}{\varepsilon_{f}}
$$

Where:

$$
\begin{aligned}
& \sigma_{c}-\text { stresses at the limit of strength (MPa), } \\
& \begin{aligned}
\sigma_{\text {res }} & \text { residual strength of the rock when testing sam- } \\
& \text { ples (MPa), } \\
\mathrm{e}_{f} & - \text { longitudinal deformation in the area of reducing } \\
& \text { the overall strength (un.). }
\end{aligned}
\end{aligned}
$$


The residual strength of a certain mining rock is simply defined as a fraction of the ultimate strength. In order to obtain more accurate data, it is established experimentally or experimentally-analytically. In the first case, laboratory tests of rock samples are carried out with the establishment of the necessary characteristics, and in the second - the existing methods are used, the initial data to which the experimental data is compared.

In the work (Tutluoglu et al., 2015), based on the results of tests of rock samples, a correlation dependence is proposed to determine the relative strength of the rock mass, which is shown by Equation 4:

$$
\frac{\sigma_{r e s}}{\sigma_{\tilde{n} s}}=-0.2 \ln \sigma_{c s}+0.93
$$

The initial characteristic in Equation 4 is only the ultimate strength of the mining rock in the sample, which makes the expression easy to use and allows for operational calculations. However, the expression is generalized and is based on the results of tests of igneous, metamorphic and sedimentary rocks in a wide range of strength $(1.2 \ldots 89.6 \mathrm{MPa})$. For sedimentary rocks, the dependence also takes the form of $\sigma_{\text {res }} \sigma_{c}=-a \ln \sigma_{c s}+b$, but the values of the coefficients $a$ and $b$ may differ from those given in Equation 4. To determine these coefficients, it is sufficient to use the known strength characteristics of the respective rocks.

Since the nature of deformation of the rock mass in the area of inelastic deformations around the roadway is similar to their deformation in the sample, which is deformed in the mode of given deformations (Hapieiev, 2014), it is assumed that a loss of the bearing capacity of rocks between their characteristics in nature and samples, proportionality remains, in particular Equation 5:

$$
\frac{R_{r e s}}{R_{c}} \approx \frac{\sigma_{r e s}}{\sigma_{c}}
$$

Where:

$R_{\text {res }}$ - resistance of rocks to compression at the limit of residual strength $(\mathrm{MPa})$,

$R_{c}$ - resistance of rocks to compression at the limit of ultimate strength $(\mathrm{MPa})$.

The resistance of rocks to compression at the ultimate strength, taking into account the disturbance of rocks, their water content and rheological properties, is determined by Equation 6 (Bondarenko et al., 2008):

$$
R_{c}=\sigma_{c s} k_{c} k_{w} k_{t}
$$

Where:

$k_{w}$ - coefficient that takes into account the softening of watered rocks as a result of filtration on the water mass (un.), $\left(k_{w}=0.4 \ldots 0.8\right)$,

$k_{t}$ - coefficient that takes into account the reduction of rock resistance to uniaxial compression under prolonged loading (un.). It is determined by Equation 7:

$$
k_{t}=\sqrt{1-\frac{x}{\beta}}
$$

Where:

$x / \beta$ - rheological indicator (un.) (Bondarenko et al., 2008).

So, the resistance of rocks to compression at the ultimate strength is determined by Equations 8:

$$
R_{\text {res }}=\sigma_{\text {res }} k_{c} k_{w} k_{t}
$$

According to the above method, it is possible to determine the parameters of the deformation diagram of the rock mass, which can be the initial data for assessing the condition of adjoining rocks around the mine roadways.

\section{Results and Discussion}

Consider the conditions of stability of mine roadways and protective constructions on the basis of the proposed method. To do this, use the known mechanical characteristics of mine rocks of the South-Donbas and Pokrovsk coal-bearing areas and the Western Donbas which are given in works (Bondarenko et al., 2008; Melnikov, 1975).

On the basis of limit values of mechanical characteristics of mine rocks of these regions, we specify the correlation dependence of the strength of the host rocks on the conditional instantaneous modulus of their deformation (see Figure 7), which has the form of Equation 9:

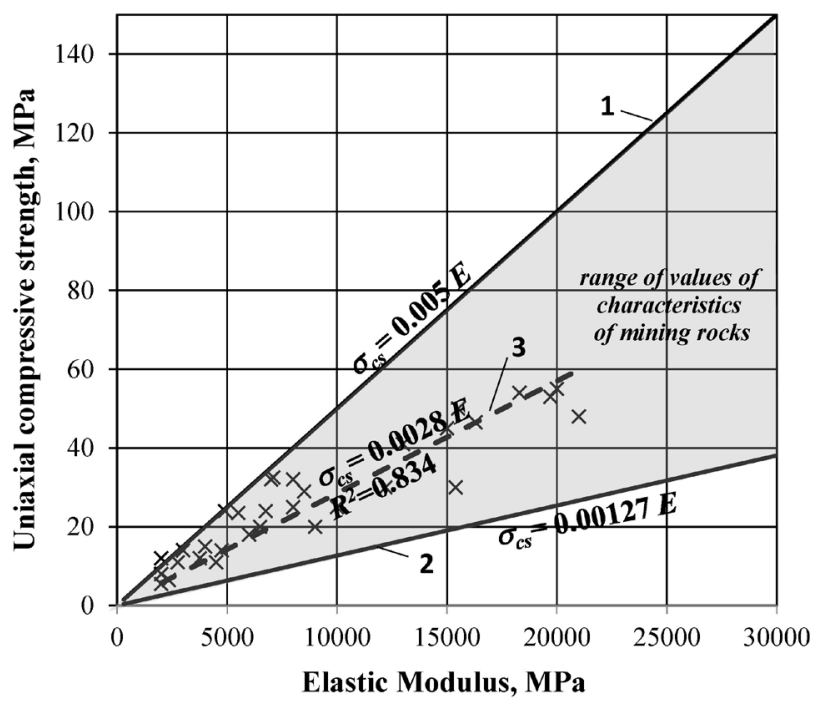

Figure 7: Limiting graphs of the dependence of the strength of rocks on the conditional instantaneous modulus of their deformation to establish the range of values of these characteristics: 1- for typical rocks of America (Deere and Miller, 1966), 2- for carbonates (Rzhevskyi and Novyk, 1984), 3- dependence graph for the host rocks of the South Donbas, Pokrovsk and the Western Donbas coal-bearing areas, $\sigma_{c s}$ - uniaxial compressive strength, $E$ - Elastic Modulus, $x$ - markers according to the data given in the works (Bondarenko et al., 20o8) and (Melnikov, 1975) 


$$
\sigma_{\tilde{n} s}=0.0028 E
$$

In Equation 9, the multiplier 0.0028 is the critical longitudinal deformation $\mathrm{e}_{\text {lim }}$ for soft adjoining rocks in the conditions of the South Donbas, Pokrovsk and the Western Donbas coal-bearing areas.

The parameters of the descending section of the rock deformation diagram (see Figure 6) must be determined. According to (Fadeev, 1987) the ratio e/ $\mathrm{e}_{\text {lim }}$ is equal to 3.0, but in the work (Babyiuk, 2005) the range from 2.8 to 3.4 is specified. So, at the moment of reaching the limit of the descending section and the residual strength section, the overall longitudinal deformations of the rock $\left(\mathrm{e}_{\text {lim }}+\mathrm{e}_{f}\right)$ are $0.012(12 \%)$, above which the rocks pass into the area of destroyed rocks (see Figure 5). In this area, the rocks have a constant residual strength and are cyclically deformed when it is exceeded by stresses from the rock mass. On each deformation cycle, there is a load of the destroyed rock volume which leads to the closing of cracks in it and the formation of structural bonds, after which their quasi-elastic deformation with the modulus $E_{n}$ (see Figure 6) is observed until the current stresses exceed the residual strength again. After that, the cycles can be repeated, and each cycle is accompanied by shifts in the surrounding rocks. This mechanism explains the deformation processes in the area of the destroyed rocks, including the subsidence of the means of protection relative to the surface of the underlying rocks. This subsidence occurs when the stresses on the part of the structure exceed the compressive strength of the rocks at the limit of residual strength. More often it occurs in the area of bearing pressure, where there is an increase in stress over the means of protection.

To determine the relative residual strength of soft sedimentary mine rocks, a correlation dependence of the relative residual strength on their ultimate strength in the sample for uniaxial compression has been established for the characteristics of rocks of the coal-bearing mass of the Western Donbas. Dependence is graphically shown in Figure 8 and has the form of Equation 10:

$$
\frac{\sigma_{r e s}}{\sigma_{c s}}=-0.1 \ln \sigma_{c s}+0.47
$$

The resulting regression dependence has a coefficient of determination of 0.94 for significant $t$ and $F$ - criteria, demonstrating an extremely close relationship between relative residual strength and ultimate strength $\left(R^{2}=0.94\right.$; $\left.t>t_{\text {lim }}(102.19>3.18) ; F>F_{\text {lim }}(25.14>9.55)\right)$. The residual strength values determined from Equation 10 for sedimentary rocks, under equal conditions, are two times less than those determined by Equation 4. Therefore, to determine the residual strength of sedimentary rocks, Equation 10 is more acceptable.

So, the resistance of rocks to compression at the ultimate strength for these conditions is determined by Equation 11 from Equations 8 and 10:

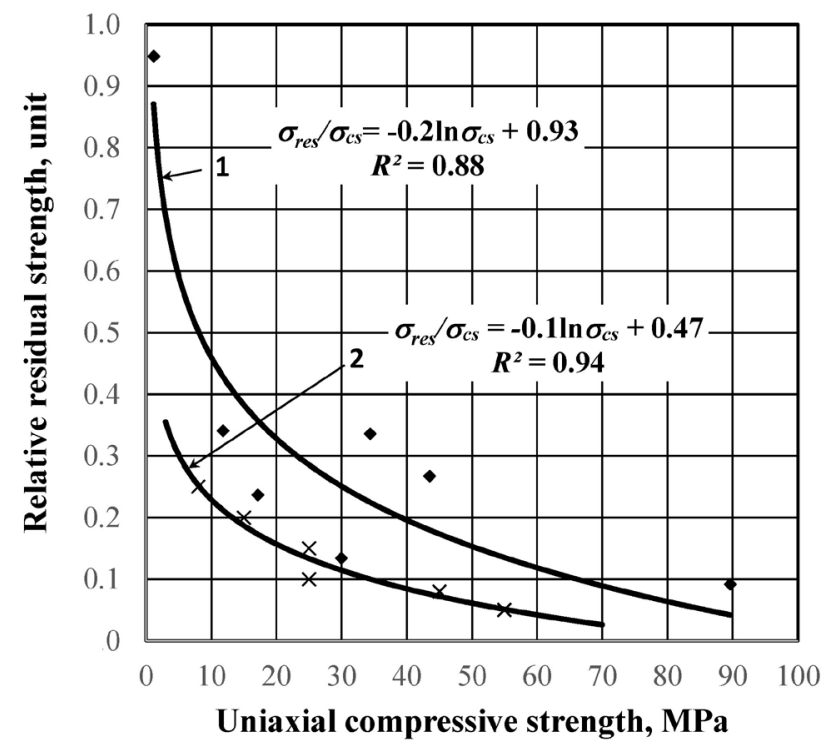

Figure 8: Graphs of the dependence of the relative residual strength of rocks on their ultimate strength in the sample for uniaxial compression: 1- according to research (Tutluoglu et al., 2015), 2- obtained for carbonaceous sedimentary rocks,

$\sigma_{\text {res }}$ - residual strength of the rock when testing samples,

$\sigma_{c s}$ - the strength limit of rocks in the sample for uniaxial compression

$$
R_{r e s}=\left[0.47-0.1 \ln \sigma_{c s}\right] \sigma_{c s} k_{c} k_{w} k_{t}
$$

From the means of protection, the load with stresses $k$ $\gamma H$ affects the underlying rocks. To ensure the stability of rocks under the means of protection, the condition which must be met is $R_{\text {res }}{ }^{3} k^{\prime} \gamma H$ or $R_{\text {res }} / k^{\prime} \gamma H^{3}$. This ratio can be considered a criterion for the stability of rocks $k_{s t}$, underlying the means of protection, which is determined by Equations 12 and 13:

$$
\begin{gathered}
k_{s t}=\frac{R_{r e s}}{k^{\prime} \gamma H}, \\
k_{s t}=\frac{\left[0.47-0.1 \ln \sigma_{c s}\right] \sigma_{c s} k_{c} k_{w} k_{t}}{k^{\prime} \gamma H}
\end{gathered}
$$

Where:

$k_{s t}$ - the criterion for the stability of rocks (un.),

$k^{\prime}-$ is the coefficient of stress concentration at the contact of the protection means and the footwall rocks (un.), $\left(k^{\prime}=1.0 \ldots 1.3\right)$ (Nehrii and Nehrii, 2020).

If $k_{s t}{ }^{3} 1$, the underlying rocks remain stable, but at $k_{s t}<1$ - they are pressed under the protective construction, so the condition of their stability takes the form of Condition 14:

$$
\left[0.47-0.1 \ln \sigma_{c s}\right] \sigma_{c s} k_{c} k_{w} k_{t} \geq k^{\prime} \gamma H
$$

If Condition 14 is not met, there is a subsidence of the protective construction relative to the surface of the footwall. In this case, the relative total subsidence of the means of protection should be determined by Equation 
15, which has been obtained by the results of numerical simulations (Nehrii and Nehrii, 2019):

$$
\varepsilon^{*}=0.835\left(1-\frac{2 \mu_{i}^{2}}{1-\mu_{i}}\right) \frac{k^{\prime} \gamma H}{E_{i}}
$$

Where:

$$
\begin{aligned}
& \mathrm{e}^{*}-\text { total subsidence of the means of protection (un.), } \\
& \mu_{n}-\text { coefficient of relative transverse deformation of } \\
& \text { the footwall rocks (un.), } \\
& \begin{array}{c}
E_{n}-\text { modulus of deformation of rocks at the limit of } \\
\text { residual strength (MPa). }
\end{array}
\end{aligned}
$$

The natural resistance of the underlying rocks $R_{\text {res }}$ is determined experimentally or with Equation 11. If the natural resistance is not enough to ensure the stability of the underlying rocks, then through the use of technological measures (anchoring the footwall, compaction, injection strengthening of destroyed rocks by binders, etc.) it is necessary to increase it up to $R_{\text {res }}$. Due to such measures, it is possible not only to change the deformation properties of the rock mass, but also to qualitatively modify its over-limiting behavior.

In general, the stability of the geotechnical system «protective construction - adjoining rocks" should be provided both by increasing the stability of the footwall rocks, and by increasing the bearing capacity of the protective construction. The condition for the stability of the geotechnical system "protective construction - adjoining rocks" is to ensure a balance between the operating stresses of the roof rocks $k^{\prime} \gamma H$ (MPa), the bearing capacity of the protective means $P_{\text {constr }}$ and the resistance of the underlying rocks $R_{r e s}$. To do this, Condition 16 must be met:

$$
\min \left(P_{\text {constr }} ; R_{\text {res }}\right) \geq k^{\prime} \gamma H
$$

Where:

$P_{\text {constr: }}$ - the bearing capacity of the protective means (MPa),

$R_{r e s} \quad$ - resistance of rocks to compression at the limit of residual strength (MPa).

At the moment, there are technologies for the protection of development roadways, which are based on the management of the stress-strain state of the rocks around the roadway and the strengthening of soft footwall rocks under the means of protection. However, these technologies are designed for certain conditions, and in most cases, they are expensive and time consuming. Additional research in this direction is still needed.

\section{Conclusions}

As a result of identifying new approaches to solving the problem of ensuring the stability of the development roadways, which are supported behind the faces, by managing the stress around the means of protection or increasing the bearing capacity of the destroyed rocks around them, the following conclusions have been made:
1. The underlying rocks of the footwall at the time of construction of the means of protection are in the stage of over-limiting deformation and their resistance is determined by the residual strength;

2. The correlation between the relative residual strength of sedimentary rocks with their ultimate compressive strength to determine the resistance of destroyed rocks to compression at the limit of residual strength, taking into account their water content, fracture and rheological properties;

3. The subsidence of the protective means relative to the surface of soft underlying rocks is cyclic and occurs in the area of residual friction of destroyed rocks, when the total longitudinal deformation of the rock layer exceeds $12 \%$, and the stress from the protective means exceeds the resistance of rocks to compression at the limit of residual strength, accompanied by a disturbance of structural bonds in the destroyed rock volume with its subsequent compaction, due to displacements and rotations of rock segments;

4. The stability of roof rocks over the means of protection must be ensured by technical means, both in the protective construction and in the underlying rocks, which increase the bearing capacity of the protective means and resistance of these rocks or reduce the load on them through the means of protection.

\section{References}

Abdullah, R.A. and Amin, M.F.M. (2008): Verification of post failure behaviour of rock using closed-circuit servo-controlled testing machine. Bulletin of the Geological Society of Malaysia, 54, 17-20. http://doi.org/10/7186/bgsm 2008003.

Aghababaei, S., Saeedi, G. and Jalalifar, H. (2020): Risk analysis of roof fall and prediction of damaged regions at retreat longwall coal mining face. Rudarsko-geološko-naftni zbornik (The Mining, Geological, Petroleum Bulletin), 35, 3, 85-95. https://doi.org/10.17794/rgn.2020.3.9.

Alejano, L.R., Rodriguez-Dono, A., Alonso, E. and FdezManín, G. (2009): Ground reaction curves for tunnels excavated in different quality rock masses showing several types of post-failure behavior. Tunnelling and Underground Space Technology, 24, 6, 689-705. https://doi. org/10.1016/j.tust.2009.07.004.

Babijuk, G.V. (2005): A system substantiation and mining of adaptive ways of maintenance of reliability of mine workings. Sci. D. National Mining University, Dnipropetrovsk, 522 p. (in Russian)

Baklashov, I.V. and Kartozia, B.A. (1975): Rock Mechanics (Механика горных пород). Nedra, Moskow, 271 p. (in Russian - no English abstract).

Bondarenko, V., Kovalevska, I., Cawood, F., Husiev, O., Snihur, V. and Jimu, D. (2021): Development and testing of an algorithm for calculating the load on support of mine workings. Mining of Mineral Deposits, 15, 1, 1-10. https:// doi.org/10.33271/mining15.01.001. 
Bondarenko, V.I., Kovalevskaya, I.A., Simanovich, G.A. et al. (2008): Methodology for predicting displacements of the lining contour of a mine working located in a layered mass of soft rocks (Методика прогноза перемещений контура крепи выемочной выработки, расположенной в слоистом массиве слабых пород). National Mining University, Dnipropetrovsk, 69 p. (in Russian - no English abstract).

Brady, B.H.G. and Brown, E.T. (2006): Rock Mechanics for underground mining. Springer Science + Business Media, Dordrecht, 628 p. http://doi.org/10.1007/978-1-40202116-9.

Chase, F., Mark, C. and Heasley, K.A. (2002): Deep cover pillar extraction in the U.S. coalfields. Proceedings of the 21st International Conference on Ground Control in Mining, Morgantown, West Virginia, 6-8 August, 68-80.

Deere, D.U. and Miller, R.P. (1966): Engineering classification and index properties for intact rock. Air Force Weapons Laboratory, Technical Report No. AFWL-TR, New Mexico, 65-116.

Dolinar, D.R. (2010): Ground and Standing Support Interaction in Tailgates of Western U.S. Longwall Mines Used in the Development of a Design Methodology Based on the Ground Reaction Curve. Proceedings of the 29th International Conference on Ground Control in Mining, Morgantown, West Virginia, 27-29 July, 152-160.

Dychkovskyi, R., Shavarskyi, Ia., Saik, P., Lozynskyi, V., Falshtynskyi, V., and Cabana, E. (2020): Research into stress-strain state of the rock mass condition in the process of the operation of double-unit longwalls. Mining of Mineral Deposits, 14, 2, 85-94. https://doi.org/10.33271/mining14.02.085.

Fadeev, A.B. (1987): Finite element method in Geomechanics (Метод конечных элементов в геомеханике). Nedra, Moskow, 221 p. (in Russian - no English abstract).

Farmer, I. (1985): Coal mine structures. Chapman and Hall, London, 310 p. http://doi.org/10.1007/978-94-009-4834-1.

Galvin, J.M. (2016): Ground Engineering - Principles and Practices for Underground Coal Mining. Springer International Publishing Switzerland, New York, London, 684 p. https://doi.org/10.1007/978-3-319-25005-2.

Gamiy, Yu., Kostenko, V., Zavialova, O., Kostenko, T. and Zhurbynskyi, D. (2020): Identifying sources of coal spontaneous heating in mine workings using aerogas control automatic systems. Mining of Mineral Deposits, 14, 1, 120-127. https://doi.org/10.33271/mining14.01.120.

Hapieiev, S.N. (2014): Modeling and prediction of geomechanical processes in the workings of deep mines. Sci. D. National Mining University, Dnipropetrovsk, 335 p. (in Russian).

Heydari, S., Hoseini, S.H., Ghodrati, B. and Kumar, U. (2020): Resilience measurement of longwall machinery. Rudarskogeološko-naftni zbornik, 35, 3, 39-44. https://doi.org/ 10.17794/rgn.2020.3.4

Hobbs, D.W. (1971): Stress-strain behaviour of some coal measure rocks. Galliery Guard, 219, 4, 200-202.

Jie, L., Mingyang, W., Kaiwen, X., Ning, Zh. and Houxu, H. (2017): Time-dependent dilatancy for brittle rocks. Journal of Rock Mechanics and Geotechnical Engineering, 9, 6, 1054-1070. https://doi.org/10.1016/j.jrmge.2017.08.002.

Kartashov, Yu.M. Matveev, B.V., Mikheev, G.V. and A.B. Fadeev (1979): Strength and deformability of rocks (Прочность и деформируемость горных пород). Nedra, Moskow, 269 p.) (in Russian - no English abstract).

Lezina, E.G. (1992): Development of the method for determining the characteristics of rocks beyond the ultimate strength in relation to the problems of destruction and stability of curvilinear outcrops (Разработка способа определения характеристик горных пород за пределом прочности применительно к задачам разрушения $u$ устойчивости криволинейных обнажений). Ph.D. Thesis. MMI Skochinskiy, Moskow. (in Russian - no English abstract).

Lin, Q., Cao, P. and Wang, P. (2018): Study of Post-Peak Strain Softening Mechanical Behaviour of Rock Material Based on Hoek-Brown Criterion. Advances in Civil Engineering, vol. 2018, ID 6190376, 9 p. https://doi.org/10.1155/ 2018/6190376

Maslo, S.V. and Hapieiev, S.N. (2014): A method for constructing a full analytical rock deformation diagram for generating initial data of numerical problems of Geomechanics. Journal of Donetsk Mining Institute, 1 (34)-2 (35), 97-105. (in Russian).

Matveev, A.A. (2012): Investigation of the deformation and rheological properties of rocks and mass for predicting the stability of underground workings taking into account fractal geometry (Исследование деформационных $и$ реологических свойств горных пород и массивов для прогноза устойчивости подземных выработок $c$ учетом фрактальной геометрии). Ph.D. Thesis. USMU. Yekaterinburg. (in Russian - no English abstract).

Melnikov, N.V. et al. (1975): Handbook (cadastre) of physical properties of rocks (Справочник (кадастр) физических свойств горных пород). Nedra, Moskow, 279 p. (in Russian - no English abstract).

Nehrii, S. and Nehrii, T. (2020): Research of behaviour peculiarities of soft adjoining rocks around protective means. Naukovyi visnyk Donetskoho natsionalnoho tekhnichnoho universytetu. 1-2, 16-27. https://doi.org/10.31474/24157902-2019-1(2)-2(3)-54-79. (in Ukrainian).

Nehrii, S., Nehrii, T. and Volkov, S. (2018): Safety of working at the end portions longwall faces. Journal of Donetsk Mining Institute. 1 (42). 31-38 https://doi.org/10.31474 /1999-981x-2018-1-31-38. (in Ukrainian).

Nehrii, S., Nehrii, T., Bachurin, L. and Piskurska, H. (2019): Problems of mining the prospective coal-bearing areas in Donbas. E3S Web Conf. Ukrainian School of Mining Engineering, 123, 01011. https://doi.org/10.1051/e3sconf $/ 201912301011$.

Nehrii, S., Nehrii, T., Kultaev, S. and Zolotarova, O. (2020): Providing resistance of protection means on the soft adjoining rocks. E3S Web Conf. II International Conference Essays of Mining Science and Practice, 168, $00033 \mathrm{https}: / /$ doi.org/10.1051/e3sconf/202016800033.

Nehrii, S., Sakhno, S., Sakhno, I. and Nehrii, T. (2018): Analyzing kinetics of deformation of boundary rocks of mine 
workings. Mining of Mineral Deposits, 12, 4, 115-123. https://doi.org/10.15407/mining12.04.115.

Norouzi Masir, R., Ataei, M., Sereshki, F. and Nouri Qarahasanlou, A. (2021): Availability simulation and analysis of armored face conveyor machine in longwall mining. Rudarsko-geološko-naftni zbornik (The Mining-Geological-Petroleum Engineering Bulletin), 36, 2, 69-81. https:// doi.org/10.17794/rgn.2021.2.7.

Petrenko, J.A. (2008): Geomechanics bases of saving of stability of making of deep mines on the different stages of their exploitation. Sci. D. Donetsk National Technical University. Donetsk. 354 p. (in Russian).

Ruppeneit, K.V. (1975): Deformability of fractured rock mass (Деформируемость массивов трещиноватых горных nород). Nedra, Moskow, 223 p. (in Russian - no English abstract).

Rzhevskiy, V.V. and Novik, G.Ya. (1984): Fundamentals of Rock Physics (Основы физики горных пород). Nedra, Moskow, 359 p. (in Russian - no English abstract).

Santarelli, F.J. (1987): Theoretical and experimental investigation of the stability of the axisymmetric wellbore. Ph.D. Thesis. Imperial College of Science and Technology. London, $472 \mathrm{p}$.

Shashenko, O.M., Sdvizhkova, O.O. and Hapieiev, S.M. (2008): Deformation and strength of mining rock mass (Деформованість та міџність масивів гірських порід). NMU, Dnipropetrovsk, 224 p. (in Ukrainian - no English abstract).

Singh, R.N. and Ghose, A.K. (2006): Engineered Rock Structures in Mining and Civil Construction. Taylor \& Francis, CRC Press, London, New York, 520 p.
Solodyankin, A.V. (2009): The geomechanic models in the system of geomonitoring in deep coal mines and methods of providing stability of long workings. Sci. D. National Mining University. Dnipropetrovsk. 429 p. (in Russian).

Tutluoğlu, L., Öge, İ.F. and Karpuz, C. (2015): Relationship Between Pre-failure and Post-failure Mechanical Properties of Rock Material of Different Origin. Rock Mech. Rock Eng., 48, 121-141 http://doi.org/10.1007/s00603014-0549-1.

Yang, P., Wu, X. and Chen, J. (2018): Elastic and plastic-flow damage constitutive model of rock based on conventional triaxial compression test. International Journal of Heat and Technology, 36 (3), 927-935 http://doi.org/10.1016/j. cageo.2006.02.011.

Zhao, Jj. and Zhang, Y. (2017): Studies on rock failure of layered rock in underground mining-face and control techniques. Geomechanics and Geophysics for Geo-Energy and Geo-Resources, 3, 405-414. https://doi.org/10.1007/ s40948-017-0068-0.

Zong, Y., Han, L., Meng, Q. and Wang, Y. (2020): Strength properties and evolution laws of cracked sandstone samples in re-loading tests. International Journal of Mining Science and Technology, 30, 251-258. https://doi. org/10.1016/j.ijmst.2019.03.004.

\section{Internet sources:}

URL1: https:/ukrmet.dp.ua/2011/07/30/ukraina-dokazannyezapasy-uglya-sostavlyayut-338-mlrd-t.html (accessed 1st April 2021)

\section{SAŽETAK}

\section{Istraživanje geomehaničkih svojstava stijena male tvrdoće smještenih uz zaštitne konstrukcije}

Razmatrani su uvjeti kod otkopavanja ugljena u rudnicima Ukrajine. Problem je otkopavanje ugljena metodom širokoga čela kada su stijene male tvrdoće („mekane”), je je time otežana zaštita rudničkih prostorija i cesta smještenih u blizini radilišta. U takvim slučajevima zaštitne konstrukcije postaju beskorisne jer se utiskuju u podinske stijene na radilištu. U radu su uspoređeni rezultati studija koje su ispitivale uvjete loma stijena ispod rudničkih prostorija (potkopa) te fizička i mehanička svojstva ugljena i okolnih stijena male tvrdoće. Iz toga je bilo moguće izračunati varijable stijenske deformacije te odrediti kriterije stabilnosti podinskih stijena. Zatim su utvrđeni uvjeti stabilnosti za geotehnički sustav „zaštitne konstrukcije - okolne stijene”. On je temelj za novi pristup u održavanju rudničkih prostorija, poglavito u prostoru iza čela radilišta, a uz kontrolu pritiska na i u stijenskome sustavu. Tako se mogu kontrolirati i uvjeti u rudničkim prostorijama, posebno onima koje služe za odvoz sirovine, a okružene su stijenama male tvrdoće.

\section{Ključne riječi:}

širokočelno otkopavanje, stijene male tvrdoće, zaštitne konstrukcije, lom stijene, kriteriji stabilnosti stijene, kriteriji stabilnosti

\section{Author's contribution}

Serhii Nehrii (PhD, associate professor): initialized the idea, developed a methodological approach, established dependencies and criteria, managed the whole process and supervised it from the beginning to the end. Tetiana Nehrii (PhD, associate professor): performed analytical processing of the calculation results, construction of graphs. Oksana Zolotarova $(\mathrm{PhD}$, associate professor): submitted and reviewed the paper. Serhii Volkov (senior lecturer): analyzed the literary sources of information. 